\title{
Comparison of the anthropometric profiles of elite youth rugby union players
}

\author{
Cristian Solís Mencía ${ }^{1,2}$, Juan J. Ramos Álvarez³, Rafael Ramos Veliz, Mikel Aramberri Gutiérrez,5, \\ Francisco Javier Calderón Montero 6
}

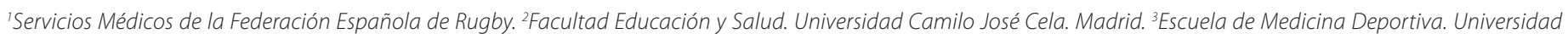
Complutense. Madrid. ${ }^{4}$ Centro de Estudios Universitario Cardenal Spindola CEU. Sevilla. ${ }^{5}$ Alai Sports Medicine Clinic. Madrid. ${ }^{6}$ Facultad de Ciencias de la Actividad Física y el Deporte. INEF. Universidad Politécnica de Madrid. Madrid.

doi: 10.18176/archmeddeporte.00032

Received: 08/05/2020 Accepted: 09/01/2021

Key words: Anthropometric. Rugby. Body composition. Somatotype.

\section{Summary}

Background: Anthropometric evaluation of athletes is necessary to optimize talent identification and player development The aim was to describe the anthropometric characteristics of national under-18 and under-20 rugby team by field positions in two season.

Material and method: 152 players of under-18 and under-20 rugby teams were to measured mass, stature, skinfolds, percentage body fat, skeletal muscle mass, bone mineral and somatype between 2015-2016 and 2016-2017 season. Mean and standard deviation were calculated for each national team, groups and positional. The Mann-Whitney $U$ test were performed to investigate differences between national team and by groups. The Kruskal-Wallis test was performed to investigate differences between positional.

Results: The foward units were heavier, taller and had a larger percentage body fat and skeletal muscle mass than back units $(p<0.05)$. The props had a larger percentage body fat $(p<0.05)$ and the seconds row were taller $(p<0.05)$.

Conclusions: The elite players of under-20 in Spain are heavier and have a larger percentage body fat and skeletal muscle mass than elite players of under-18. The foward units are heavier, taller and have a larger percentage body fat, skeletal muscle mass and bone mineral tan back units. The props are heavier positional and have larger percentage body fat. The seconds row are taller positional.
Palabras clave: Antropometría. Rugby. Composición corporal. Somatotipo.

\section{Perfil antropométrico comparativo entre jugadores juveniles de rugby de élite}

\section{Resumen}

Introducción: La evaluación antropométrica de los deportistas es necesaria para optimizar la identificación y el desarrollo de los jugadores. Nuestro objetivo es describir las características antropométricas por posición en los jugadores de las selecciones de rugby XV Sub18 y Sub20 durante dos temporadas.

Material y método: A 152 jugadores de las selecciones de rugby XV Sub18 y Sub20 de España se les midió la estatura, masa corporal, pliegues cutáneos, porcentaje de tejido graso, masa muscular esquelética (MME), masa mineral ósea (MMO) y somatotipo durante las temporadas 2015-2016 y 2016-2017. Se calculó el promedio y la desviación estándar para cada selección, grupo y posición. Se realizó el análisis de U de Mann-Whitney para comparar entre selecciones y por grupos. Para comparar entre posiciones se utilizó la prueba de Kruskal-Wallis.

Resultados: Los jugadores agrupados como delanteros presentan mayor masa corporal, estatura, porcentaje de tejido graso, MME y MMO que los tres cuartos ( $p<0,05)$. Los jugadores que ocupan la posición de piliers presentan mayor porcentaje de tejido graso $(p<0,05)$ y los que ocupan la posición de segunda línea son los de mayor estatura $(p<0,05)$.

Conclusiones: Los jugadores de élite en España Sub20 presentan mayor masa corporal, porcentaje de tejido graso y MME que los jugadores élite de España Sub18. Los jugadores agrupados como delanteros de nivel élite en España Sub18 y Sub20 presentan mayor masa corporal, estatura, porcentaje de tejido graso, MME y MMO que los jugadores agrupados como tres cuartos. La posición con mayor masa corporal y porcentaje de tejido graso es la de piliers en los jugadores de élite de España en las categorías Sub18 y Sub20. Los jugadores de nivel élite que ocupan la posición de segundas líneas son los de mayor estatura en España en las categorías Sub18 y Sub20. 


\section{Introduction}

Fifteen-a-side rugby union is a contact sport played on a field between two teams. The nature of the modern game means that all the players need to be able to make intermittent high-intensity efforts during a match which involve sprinting, tackling and competing in rucks, mauls and scrums. Within each team, there are two distinct groups of players (forwards and backs), and each player is given a number which represents their precise position within each group'. In each group, the players perform tasks specific to their position during a match. The forwards wear the numbers ${ }^{1-8}$, and the backs wear the numbers ${ }^{9-15}$. The forwards are frequently involved in physical clashes with the members of the opposing team, securing possession of the ball in scrums, lineouts, rucks (contact situation in open play in which the ball is on the ground, and one or more players from each team close around it while remaining on their feet) and mauls (contact situation in open play that occurs when the ball carrier is held by an opponent and one or more of the ball carrier's team mates bind onto him/her) ${ }^{2-4}$. They need to be able to pass the ball in limited areas of the field when attacking. While the backs need to secure possession of the ball in tackles and rucks, their main role is to evade defenders while carrying it in wide open spaces on the field ${ }^{2-4}$. Based on this overview of the game, the forwards are slower and stronger than the backs, and the backs are faster and more agile ${ }^{5,6}$. The completely different roles played by the forwards and the backs would suggest the need for specific anthropometric profiles in order to develop effective and safe skills during games?

The morphology of rugby players has changed over the last century. In the last 25 years, their mean body mass has increased at a rate three to four times greater than in the previous 75 years $^{8}$, with taller backs and heavier forwards 9 . In rugby, high body mass is usually a predictor of success8. During the static phases focussing on ball retention, high body mass (regardless of composition) is an advantage because it represents an external load that the other team has to try to move in scrums. During the dynamic phases of a game, however, the determining factor of play is the ability to accelerate and decelerate, along with a player's power to body mass ratio (which is always influenced by body composition $)^{10}$. High relative fat mass is associated with high energy expenditure ${ }^{1,11}$, which leads to a greater risk of traumas and overuse injuries when the physical characteristics of the athlete are not optimal for the role their position dictates ${ }^{12}$. In conclusion, high body mass per se is an advantage in the static phases of the game, which are more common at low competitive levels. However, a specific relationship between lean body mass and fat mass is needed in most of the dynamic actions which characterise modern rugby and, consequently, is also required to achieve optimum performance ${ }^{13,14}$. An anthropometric assessment of players by gender, position and age may provide an evaluation that could improve talent identification, training methodologies, injuryprevention strategies and monitoring of changes in body composition over the season $n^{1,15}$.
Body composition data are limited for fifteen-a-side rugby ${ }^{4}$, few studies existing to date which provide anthropometric data for younger players by position. Due to the different physical demands that players in different positions face ${ }^{1,2}$, a comparative anthropometric study of Spanish youth-level rugby players by position is needed, this being the first study to provide such data.

We aim to describe the anthropometric characteristics of the Spain U18 and U20 international rugby squads by position over two seasons.

\section{Materials and methods}

The players in the Spain men's international rugby squads in the U18 and U20 categories were studied in the 2015-2016 and 2016-2017 seasons. Assessment was carried out at each squad's training camp each season. All the participants and/or their legal guardians were informed about the purpose of the study and gave their written consent to participate. The study complied with the Declaration of Helsinki for research involving human subjects and was approved by the Ethics Committee at the Clinical Hospital of the Complutense University of Madrid.

\section{Subjects}

A total of 152 different players were studied in the 2015/2016/2017 seasons, conducting a total of 166 assessments, 14 players repeating in the two squads in the seasons studied. Sixty-six belonged to the U18 category and one hundred to the U20 category. The players were divided into two groups: forwards and backs. They were also subdivided into 9 subgroups according to their positions on the field: props, hookers, second row, back row, scrum-halves, fly-halves, centres, wings and full-backs.

\section{Anthropometry}

Body mass and height were measured on the first day of the training camp before breakfast, with the players only wearing shorts. Body mass was measured with a digital scale (Seca 877, Seca, Leicester, UK) and height with a wall-mountable height rod (Seca 206, Seca, Leicester, UK). The skinfolds, circumferences and diameters of all the players were measured by the same researcher. A total of eight folds (biceps, triceps, subscapular, suprailiac, supraspinal, abdominal, front thigh and medial calf) were measured three times with a manual caliper (Innovare 4 Cescorf, Porto Alegre, Br). In the same session, three bone diameters (medial epicondyle of the humerus to the lateral epicondyle, radial styloid process to the ulnar styloid process and medial condyle of the femur to the lateral condyle) were measured with a pachymeter (Cescorf, Porto Alegre, Br) and 4 muscle circumferences (arm relaxed, arm flexed, mid-thigh and calf) with a tape measure (Cescorf, Porto Alegre, Br).

The mean was calculated for each fold (after eliminating any possible outliers in the event of a difference greater than $1 \mathrm{~mm}$ ). The sum of 8 folds was obtained. Body mass index (BMI), body fat percentage 
(Carter equation $\left.{ }^{16}\right)$, skeletal muscle mass (Lee equation ${ }^{17}$ ) and bone mineral mass (Rocha equation ${ }^{18}$ ) were also calculated. Somatotyping was performed using the Heath-Carter method ${ }^{19}$.

\section{Statistics}

The mean and standard deviation, with a confidence interval of 95\%, were calculated for each squad, group (forwards and backs) and position (props, hookers, second row, back row, scrum-halves, fly-halves, centres, wings and full-backs). The methodology proposed by HeathCarter was used for somatotyping, using the somatotype dispersion index (SDI), the mean somatotype dispersion distance (SDD) and the somatotype attitudinal mean (SAM) ${ }^{19}$. Prior to analysis of the data, the Kolmogorov-Smirnov test was used to evaluate normal distribution; non-parametric statistics was used to analyse data without normal distribution. The Mann-Whitney $U$ test was applied to compare by squad and by group. The Kruskal-Wallis test was used to compare by position. Comparison with other studies was performed with the independent samples $t$ test and the somatotypes were compared with SDD. Data analysis was performed using SPSS for Windows version 20.

\section{Results}

Table 1 shows the descriptive values of anthropometric measurements obtained by category (U18 and U20), Table 2 the values obtained by field position (forwards and backs), and Tables 3 and 4 the values obtained for each field position by team category.

\section{Comparison between categories (U18 and U20)}

Height: Comparing each squad by group (Table 3) shows that there is no significant difference in height between the forwards in the two squads, the $U 18$ forwards measuring $1.83 \pm 0.07 \mathrm{~m}$ and the $\mathrm{U} 20$ players measuring $1.84 \pm 0.06 \mathrm{~m}$. The same occurs with the backs (Table 4), where the height in the U18 squad is $1.79 \pm 0.06 \mathrm{~m}$, while in the $\mathrm{U} 20$ squad it is $1.79 \pm 0.05 \mathrm{~m}$. However, when the forwards are compared with the backs (Table 2), differences are observed $(p<0.005)$.

Body mass: In relation to body mass and BMI, there are significant differences between the forwards in the two squads, the U18 players

Table 1. Anthropometric values by team category.

\begin{tabular}{lccc}
\hline & $\begin{array}{c}\text { U18 squad } \\
(\mathbf{n}=66)\end{array}$ & $\begin{array}{c}\text { U20 squad } \\
(\mathbf{n}=\mathbf{1 0 0})\end{array}$ & $\mathbf{p}$ \\
\hline Weight & $86.6 \pm 11.7$ & $93.2 \pm 16.2$ & $0.016^{*}$ \\
Height & $1.81 \pm 0.07$ & $1.82 \pm 0.06$ & 0.305 \\
BMI & $26.25 \pm 3.1$ & $28.02 \pm 4.3$ & $0.012^{*}$ \\
BF & $10.43 \pm 3.6$ & $12.62 \pm 4.8$ & $0.01^{*}$ \\
\hline
\end{tabular}

BMI: Body mass index; BF: Body fat; p: U Mann-Whitney p-value;

*statistically significant difference: $p<0.05$.
Table 2. Comparison of anthropometric variables by group of players.

\begin{tabular}{|c|c|c|c|c|}
\hline & & $\begin{array}{c}\text { Forwards } \\
\text { (n: 95) }\end{array}$ & $\begin{array}{l}\text { Backs } \\
\text { (n: 71) }\end{array}$ & $P$ \\
\hline \multirow[t]{2}{*}{ Weight } & $95 \% \mathrm{Cl}$ & $98.9 \pm 13.6$ & $79.5 \pm 7.5$ & $0.000^{* * *}$ \\
\hline & & $96.16-101.71$ & $77.75-81.30$ & \\
\hline \multirow[t]{2}{*}{ Height } & $95 \% \mathrm{Cl}$ & $1.83 \pm 0.06$ & $1.79 \pm 0.06$ & $0.000^{* *}$ \\
\hline & & $1.82-1.85$ & $1.77-1.80$ & \\
\hline \multirow[t]{2}{*}{ BMI } & $95 \% \mathrm{Cl}$ & $29.2 \pm 4.0$ & $24.7 \pm 1.9$ & $0.000^{* *}$ \\
\hline & & $28.44-30.10$ & $24.25-25.18$ & \\
\hline \multirow[t]{2}{*}{$\%$ body fat } & $95 \% \mathrm{Cl}$ & $13.6 \pm 4.8$ & $9.1 \pm 2.1$ & $0.000^{* *}$ \\
\hline & & $12.68-14.65$ & $8.68-9.69$ & \\
\hline \multirow[t]{2}{*}{$\sum 8$ folds } & $95 \% \mathrm{Cl}$ & $135.7 \pm 57.6$ & $80.9 \pm 27.1$ & $0.000^{* *}$ \\
\hline & & $124.03-147.51$ & 74.54-87.38 & \\
\hline \multirow[t]{2}{*}{ SMM } & $95 \% \mathrm{Cl}$ & $33.8 \pm 3.1$ & $30.4 \pm 2.7$ & $0.000^{* *}$ \\
\hline & & $33.22-34.50$ & $29.78-31.08$ & \\
\hline \multirow[t]{2}{*}{ BMM } & $95 \% \mathrm{Cl}$ & $13.6 \pm 1.3$ & $12.4 \pm 1.1$ & $0.000^{* *}$ \\
\hline & & $13.38-13.93$ & $12.17-12.71$ & \\
\hline \multicolumn{5}{|l|}{ Somatotype } \\
\hline \multirow[t]{2}{*}{ Endomorphic } & $95 \% \mathrm{Cl}$ & $4.4 \pm 1.8$ & $2.6 \pm 0.9$ & $0.000^{* *}$ \\
\hline & & $4.03-4.81$ & $2.42-2.87$ & \\
\hline \multirow[t]{2}{*}{ Mesomorphic } & $95 \% \mathrm{Cl}$ & $4.7 \pm 1.1$ & $4.1 \pm 0.9$ & $0.000^{* *}$ \\
\hline & & $4.52-4.99$ & $3.90-4.35$ & \\
\hline \multirow[t]{2}{*}{ Ectomorphic } & $95 \% \mathrm{Cl}$ & $0.9 \pm 0.7$ & $1.7 \pm 0.5$ & $0.000^{* *}$ \\
\hline & & $0.83-1.12$ & $1.56-1.84$ & \\
\hline SDI & & $2.19^{*}$ & 1.69 & \\
\hline SDD & \multicolumn{4}{|c|}{$4.43^{*}$} \\
\hline SAM & \multicolumn{4}{|c|}{2} \\
\hline
\end{tabular}

BMI: Body mass index; BF: Body fat; $\Sigma 8$ folds: Sum of 8 folds; SMM: Skeletal muscle mass; BMM: Bone mineral mass: SDI: Somatotype dispersion index; SDD: Mean somatotype dispersion distance; SAM: Somatotype attitudinal mean; Cl: confidence interval 95\%; $\mathrm{p}$ Mann-Whitney test $p$-value. The asterisks indicate statistically significant differences: ${ }^{*} p<0.05$ ${ }^{* *} p<0.01$, respectively.

giving lower figures of $93.2 \pm 10.0 \mathrm{~kg}$ and $27.8 \pm 2.9 \mathrm{~kg} / \mathrm{m}^{2}$, and the U20 players higher figures of $102.3 \pm 14.4 \mathrm{~kg}$ and $30.1 \pm 4.4 \mathrm{~kg} / \mathrm{m}^{2}(p<0.05)$ No significant differences are observed between the backs in the two squads. Comparing the forwards and the backs, the weight and BMI of the forwards are greater, with $98.9 \pm 13.6 \mathrm{~kg}$ and $29.2 \pm 4.0 \mathrm{~kg} / \mathrm{m}^{2}$, while those of the backs are lower, with respective values of $79.5 \pm 7.5 \mathrm{~kg}$ and $24.7 \pm 1.9 \mathrm{~kg} / \mathrm{m}^{2}(p<0.05)$.

Body fat percentage: There are differences in body fat percentage, sum of the 8 folds and skeletal muscle mass between the forwards in the two squads and between the backs in the two squads, the values for U20 players being higher ( $p<0.05)$. Comparing forwards with backs, higher values are observed in the forwards $(p<0.05)$

Somatotype: Regarding somatotypes, it is observed that that of the forwards is heterogeneous, with an SDI of more than 2, while that of the 
Table 3. Comparison of anthropometric variables in forwards by squad.

\begin{tabular}{|c|c|c|c|}
\hline & $\begin{array}{l}\text { Forwards } \\
\text { U18 (n:36) }\end{array}$ & $\begin{array}{l}\text { Forwards } \\
\text { U20 (n:59) }\end{array}$ & $p$ \\
\hline Weight & $93.2 \pm 10.0$ & $102.3 \pm 14.4$ & $0.002^{* *}$ \\
\hline Height & $1.83 \pm 0.07$ & $1.84 \pm 0.06$ & 0.1 \\
\hline BMI & $27.8 \pm 2.9$ & $30.1 \pm 4.4$ & $0.009^{* *}$ \\
\hline$\%$ body fat & $12.0 \pm 3.7$ & $14.6 \pm 5.1$ & $0.007^{* *}$ \\
\hline$\sum 8$ folds & $114.8 \pm 45.5$ & $148.5 \pm 60.7$ & $0.003^{* *}$ \\
\hline SMM & $32.6 \pm 2.8$ & $34.5 \pm 3.0$ & $0.004^{* *}$ \\
\hline BMM & $13.5 \pm 0.2$ & $13.7 \pm 0.17$ & 0.32 \\
\hline Somatotype & & & \\
\hline Endomorphic & $3.8 \pm 1.5$ & $4.7 \pm 2.0$ & $0.02^{*}$ \\
\hline Mesomorphic & $5.3 \pm 1.3$ & $6.0 \pm 1.2$ & 0.07 \\
\hline Ectomorphic & $1.1 \pm 0.7$ & $0.8 \pm 0.6$ & 0.13 \\
\hline $\begin{array}{l}\text { SDI } \\
\text { SDD }\end{array}$ & \multicolumn{2}{|c|}{$2.21^{*}$} & \\
\hline SAM & \multicolumn{2}{|c|}{1.18} & \\
\hline
\end{tabular}

BMI: Body mass index; BF: Body fat; ¿8 folds: Sum of 8 folds; SMM: Skeletal muscle mass; BMM: Bone mineral mass; SDI: Somatotype dispersion index; SDD: Mean somatotype dispersion distance; SAM: Somatotype attitudinal mean; $p$ : Mann-Whitney test $p$-value; The asterisks indicate statistically significant differences: ${ }^{*} p<0.05 ;{ }^{* *} p<0.01$, respectively.
Table 4. Comparison of anthropometric variables in backs by squad.

\begin{tabular}{|c|c|c|c|}
\hline & $\begin{array}{c}\text { Backs } \\
\text { U18 (n:30) }\end{array}$ & $\begin{array}{c}\text { Backs } \\
\text { U20 (n:41) }\end{array}$ & $\mathbf{p}$ \\
\hline Weight & $78.7 \pm 8.2$ & $80.0 \pm 6.9$ & 0.177 \\
\hline Height & $1.79 \pm 0.06$ & $1.79 \pm 0.05$ & 0.7 \\
\hline BMI & $24.3 \pm 2.2$ & $24.9 \pm 1.7$ & 0.08 \\
\hline$\%$ body fat & $8.5 \pm 2.2$ & $9.6 \pm 1.9$ & $0.005^{* *}$ \\
\hline$\sum 8$ folds & $70.1 \pm 27.7$ & $88.8 \pm 23.9$ & $0.001^{* *}$ \\
\hline SMM & $30.4 \pm 3.0$ & $30.3 \pm 2.5$ & 0.954 \\
\hline BMM & $12.6 \pm 0.2$ & $12.3 \pm 0.15$ & 0.34 \\
\hline Somatotype & & & \\
\hline Endomorphic & $2.4 \pm 1.0$ & $2.8 \pm 0.8$ & $0.0001^{* *}$ \\
\hline Mesomorphic & $4.0 \pm 0.9$ & $4.1 \pm 0.9$ & 0.609 \\
\hline Ectomorphic & $1.8 \pm 0.6$ & $1.6 \pm 0.5$ & 0.141 \\
\hline SDI & 1.68 & 1.61 & \\
\hline SDD & \multicolumn{2}{|c|}{$3.11^{*}$} & \\
\hline SAM & \multicolumn{2}{|c|}{0.43} & \\
\hline
\end{tabular}

BMI: Body mass index; BF: Body fat; $\Sigma 8$ folds: Sum of 8 folds; SMM: Skeletal muscle mass; BMM: Bone mineral mass; SDI: Somatotype dispersion index; SDD: Mean somatotype dispersion distance; SAM: Somatotype attitudinal mean; $p$ : Mann-Whitney test $p$-value; The asterisks indicate statistically significant differences: ${ }^{*} p<0.05 ;{ }^{* *} p<0.01$, respectively.

Table 5. Comparison of anthropometric variables by position of players.

\begin{tabular}{|c|c|c|c|c|c|c|c|c|c|}
\hline & $\begin{array}{l}\text { Prop } \\
\mathrm{N}: 31\end{array}$ & $\begin{array}{c}\text { Hooker } \\
\text { N:12 }\end{array}$ & $\begin{array}{c}\text { Second row } \\
N: 23\end{array}$ & $\begin{array}{c}\text { Back row } \\
N: 29\end{array}$ & $\begin{array}{l}\text { Scrum-half } \\
\mathrm{N}: 12\end{array}$ & $\begin{array}{c}\text { Fly-half } \\
\text { N:11 }\end{array}$ & $\begin{array}{l}\text { Centre } \\
\mathrm{N}: 19\end{array}$ & $\begin{array}{l}\text { Wing } \\
N: 21\end{array}$ & $\begin{array}{c}\text { Full-back } \\
\text { N:8 }\end{array}$ \\
\hline U18 & 9 & 8 & 11 & 8 & 5 & 6 & 8 & 7 & 4 \\
\hline U20 & 22 & 4 & 12 & 21 & 7 & 5 & 13 & 12 & 4 \\
\hline Weight $(\mathrm{kg})$ & 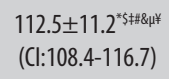 & $\begin{array}{l}88.1 \pm 4.3^{\wedge \ddagger} \\
\text { (Cl:85.3-90.8) }\end{array}$ & $\begin{array}{l}96.8 \pm 10.8^{ \pm \# 8 Q_{\mu} *} \\
(\mathrm{Cl}: 92.1-101.5)\end{array}$ & $\begin{array}{l}90.5 \pm 7.2^{\text {^抑 }} \\
(\mathrm{Cl}: 87.7-93.2)\end{array}$ & $\begin{array}{l}71.4 \pm 5.8^{\wedge+15} \\
\text { (Cl: } 67.7-75.1)\end{array}$ & $\begin{array}{l}78.9 \pm 4.1^{\wedge+5} \\
(\mathrm{Cl}: 76.1-81.7)\end{array}$ & $\begin{array}{l}84.1 \pm 7.8^{\wedge \dagger} \\
(\mathrm{Cl}: 80.5-87.7)\end{array}$ & $\begin{array}{l}79.5 \pm 6.8^{\wedge+5} \\
(\mathrm{Cl}: 76.2-82.7)\end{array}$ & $\begin{array}{l}80.3 \pm 3.7^{\wedge \dagger} \\
(\mathrm{Cl}: 77.2-83.4)\end{array}$ \\
\hline Height (m) & $\begin{array}{l}1.82 \pm 0.06^{\ddagger \ddagger} \\
\text { (Cl:1.79-1.84) }\end{array}$ & $\begin{array}{c}1.77 \pm 0.04^{\dagger} \\
(\mathrm{Cl}: 1.74-1.79)\end{array}$ & $\begin{array}{l}1.90 \pm 0.05^{\wedge * \pm+884} \\
(\mathrm{Cl}: 1.87-1.92)\end{array}$ & $\begin{array}{c}1.83 \pm 0.05^{\ddagger} \\
\text { (Cl:1.81-1.85) }\end{array}$ & $\begin{array}{l}1.72 \pm 0.03^{\wedge+5840 \%} \\
(\mathrm{Cl}: 1.69-1.74)\end{array}$ & $\begin{array}{c}1,77 \pm 0,04^{\dagger} \\
(\mathrm{Cl}: 1.73-1.80)\end{array}$ & $\begin{array}{l}1.82 \pm 0.04^{\ddagger \ddagger} \\
\text { (Cl:1.80-1.84) }\end{array}$ & $\begin{array}{l}1.81 \pm 0.05^{\ddagger \ddagger} \\
\text { (Cl:1.78-1.83) }\end{array}$ & $\begin{array}{c}1.81 \pm 0.06^{\ddagger} \\
\text { (Cl:1.75-1.86) }\end{array}$ \\
\hline $\mathrm{BF}(\%)$ & $\begin{array}{l}19.0 \pm 3.9^{+\$ \$ \# \# Q_{4} \neq} \\
(\mathrm{Cl}: 17.6-20.5)\end{array}$ & $\begin{array}{c}11.5 \pm 2.0 \\
(\mathrm{Cl}: 10.2-12.8)\end{array}$ & $\begin{array}{c}11.2 \pm 2.7^{\wedge} \\
(\mathrm{Cl}: 10.0-12.4)\end{array}$ & $\begin{array}{c}10.6 \pm 2.2^{\wedge} \\
(\mathrm{Cl}: 9.7-11.5)\end{array}$ & $\begin{array}{c}9.2 \pm 2.2^{\wedge} \\
(\mathrm{Cl}: 7.7-10.6)\end{array}$ & $\begin{array}{c}8.8 \pm 2,7^{\wedge} \\
(\mathrm{Cl}: 6.9-10.6)\end{array}$ & $\begin{array}{c}9.5 \pm 2.1^{\wedge} \\
(\mathrm{Cl}: 8.5-10.4)\end{array}$ & $\begin{array}{l}8.7 \pm 1.6^{\wedge} \\
(\mathrm{Cl}: 7.9-9.5)\end{array}$ & $\begin{array}{c}9.8 \pm 2.2^{\wedge} \\
(\mathrm{Cl}: 8.0-11.7)\end{array}$ \\
\hline
\end{tabular}

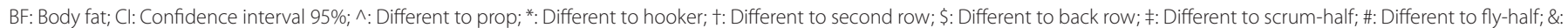
Different to centre; $\mu$ : Different to wing; $¥$ : Different to full-back.

backs is homogeneous, with an SDI below 2. The mean somatotype is different between forwards and backs (SDD> 2), between the forwards in the two squads (SDD>2) and between the backs (SDD> 2). Endomorphism is significantly different between the forwards in the two squads and between the backs in the two squads $(p<0.05)$. However, there are no significant differences when the two squads are compared by groups in terms of mesomorphism and ectomorphism. Significant differences are noted when forwards are compared with backs, endomorphism and mesomorphism being higher in the forwards, and ectomorphism being higher in the backs (Figure 1).

Position: The comparison by position is shown in Table 5. The body mass of the props is greater compared to other positions, with the sole exception of the second row, with whom no significant difference is observed. As for height, players in the second row are taller than those in other positions, save the third row and the full-backs, with whom no significant difference is observed. The body fat percentage is seen 
Table 6. Comparison of somatotype by position of players.

\begin{tabular}{|c|c|c|c|c|c|c|c|c|c|}
\hline & $\begin{array}{l}\text { Prop } \\
\text { N:31 }\end{array}$ & $\begin{array}{c}\text { Hooker } \\
\text { N:12 }\end{array}$ & $\begin{array}{c}\text { Second row } \\
N: 23\end{array}$ & $\begin{array}{c}\text { Back row } \\
N: 29\end{array}$ & $\begin{array}{c}\text { Scrum-half } \\
\mathrm{N}: 12\end{array}$ & $\begin{array}{c}\text { Fly-half } \\
\text { N:11 }\end{array}$ & $\begin{array}{c}\text { Centre } \\
\mathrm{N}: 19\end{array}$ & $\begin{array}{l}\text { Wing } \\
\mathrm{N}: 21\end{array}$ & $\begin{array}{c}\text { Full-back } \\
\text { N:8 }\end{array}$ \\
\hline U18 & 9 & 8 & 11 & 8 & 5 & 6 & 8 & 7 & 4 \\
\hline U20 22 & 4 & 12 & 21 & 7 & 5 & 13 & 12 & 4 & \\
\hline \multicolumn{10}{|l|}{ Somatotype } \\
\hline Endomorphic & $\begin{array}{l}6.6 \pm 1.3^{t 5+1+80) *} \\
(\mathrm{Cl}: 6.1-7.1)\end{array}$ & $\begin{array}{c}3.7 \pm 0.8^{\mu} \\
(\mathrm{Cl}: 3.2-4.3)\end{array}$ & $\begin{array}{c}3.3 \pm 1.0^{\wedge} \\
(\mathrm{Cl}: 2.8-3.7)\end{array}$ & $\begin{array}{c}3.2 \pm 0.9^{\wedge} \\
(\mathrm{Cl}: 2.9-3.5)\end{array}$ & $\begin{array}{c}2.8 \pm 0.9^{\wedge} \\
(\mathrm{Cl}: 2.3-3.4)\end{array}$ & $\begin{array}{c}2.5 \pm 1.2^{\wedge} \\
(\mathrm{Cl}: 1.6-3.4)\end{array}$ & $\begin{array}{c}2.7 \pm 0.8^{\wedge} \\
(\mathrm{Cl}: 2.3-3.1)\end{array}$ & $\begin{array}{l}2.3 \pm 0.7^{\wedge *} \\
\text { (Cl:1.9-2.6) }\end{array}$ & $\begin{array}{c}2.9 \pm 1.0^{\wedge} \\
(\mathrm{Cl}: 2.0-3.7)\end{array}$ \\
\hline Mesomorphic & $\begin{array}{l}6.9 \pm 0.9^{\dagger 5 \$ 8 \mu^{*}} \\
(\mathrm{Cl}: 6.6-7.3)\end{array}$ & $\begin{array}{c}5.8 \pm 0.8 \\
(\mathrm{Cl}: 5.3-6.3)\end{array}$ & $\begin{array}{c}4.7 \pm 1.1^{\wedge} \\
(\mathrm{Cl}: 4.2-5.2)\end{array}$ & $\begin{array}{c}5.2 \pm 0.8^{\wedge} \\
(\mathrm{Cl}: 4.9-5.6)\end{array}$ & $\begin{array}{c}4.9 \pm 0.8^{\wedge} \\
(\mathrm{Cl}: 4.4-5.5)\end{array}$ & $\begin{array}{c}5.3 \pm 0.6^{\wedge} \\
(\mathrm{Cl}: 4.9-5.7)\end{array}$ & $\begin{array}{l}4.7 \pm 1.0^{\wedge} \\
(\mathrm{Cl}: 4.3-5.2)\end{array}$ & $\begin{array}{c}4.4 \pm 1.1^{\wedge} \\
(\mathrm{Cl}: 3.8-5.0)\end{array}$ & $\begin{array}{c}4.5 \pm 0.7^{\wedge} \\
(\mathrm{Cl}: 3.9-5.1)\end{array}$ \\
\hline Ectomorphic & $\begin{array}{l}0.2 \pm 0.3^{+5 \pm \# \& \& u \neq} \\
(\mathrm{Cl}: 0.1-0.3)\end{array}$ & $\begin{array}{l}0.8 \pm 0.4^{8 \mu} \\
(\mathrm{Cl}: 0.5-1.1)\end{array}$ & $\begin{array}{c}1.5 \pm 0.5^{\wedge} \\
(\mathrm{Cl}: 1.3-1.7)\end{array}$ & $\begin{array}{l}1.3 \pm 0.4^{\wedge} \\
(\mathrm{Cl}: 1.1-1.5)\end{array}$ & $\begin{array}{l}1.6 \pm 0.4^{\wedge} \\
(\mathrm{Cl}: 1.3-1.9)\end{array}$ & $\begin{array}{c}1.4 \pm 0.4^{\wedge} \\
(\mathrm{Cl}: 1.1-1.8)\end{array}$ & $\begin{array}{l}1.6 \pm 0.6^{\wedge *} \\
(\mathrm{Cl}: 1.3-1.9)\end{array}$ & $\begin{array}{l}1.9 \pm 0.5^{\wedge *} \\
(\mathrm{Cl}: 1.6-2.1)\end{array}$ & $\begin{array}{c}1.8 \pm 0.8^{\wedge} \\
(\mathrm{Cl}: 1.0-2.5)\end{array}$ \\
\hline
\end{tabular}

Cl: Confidence interval 95\%; ^: Different to prop; *: Different to hooker; $†$ : Different to second row; $\$$ : Different to back row; : Different to scrum-half; \#: Different to fly-half; \&: Different to centre; $\mu$ : Different to wing; $¥:$ Different to full-back.

Figure 1. Somatochart by group of players.

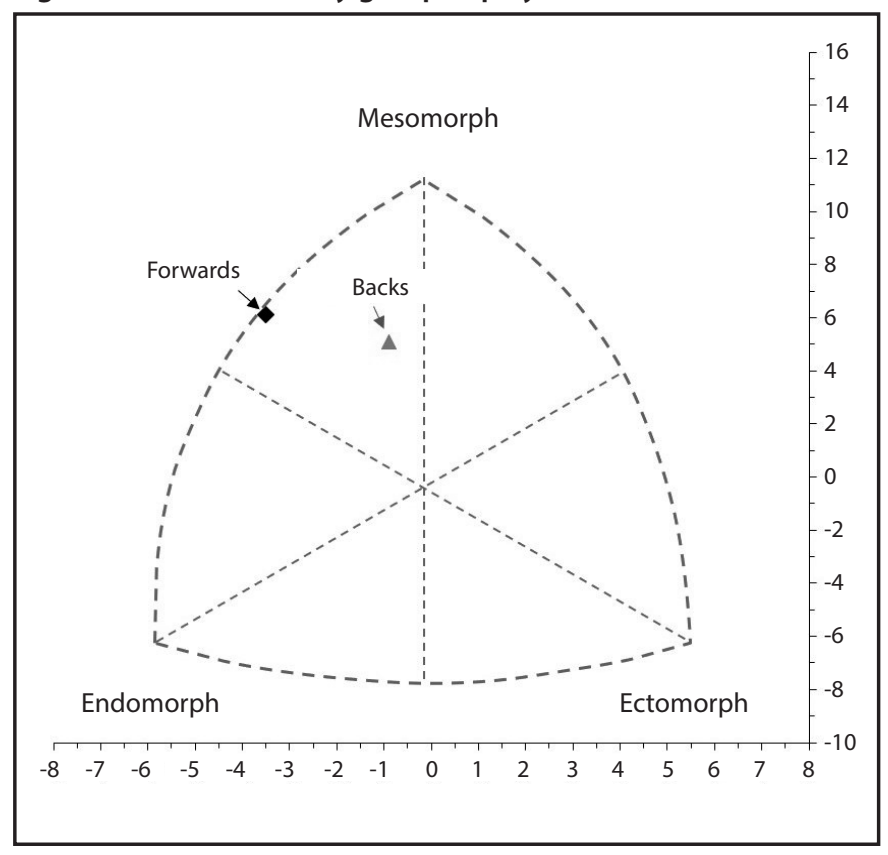

to be higher in the props when compared with other positions, with the exception of the hookers, with whom no significant difference is observed. The somatotype by position is shown in Table 6 and Figure 2.

\section{Discussion}

This is the first study focussing on the anthropometric profile of the U18 and U20 international fifteen-a-side rugby squads in Spain. The information obtained in this study is limited by only centring on the elite fifteen-a-side rugby population aged from 17 to 20. However, because
Figure 2. Somatochart by position of players.

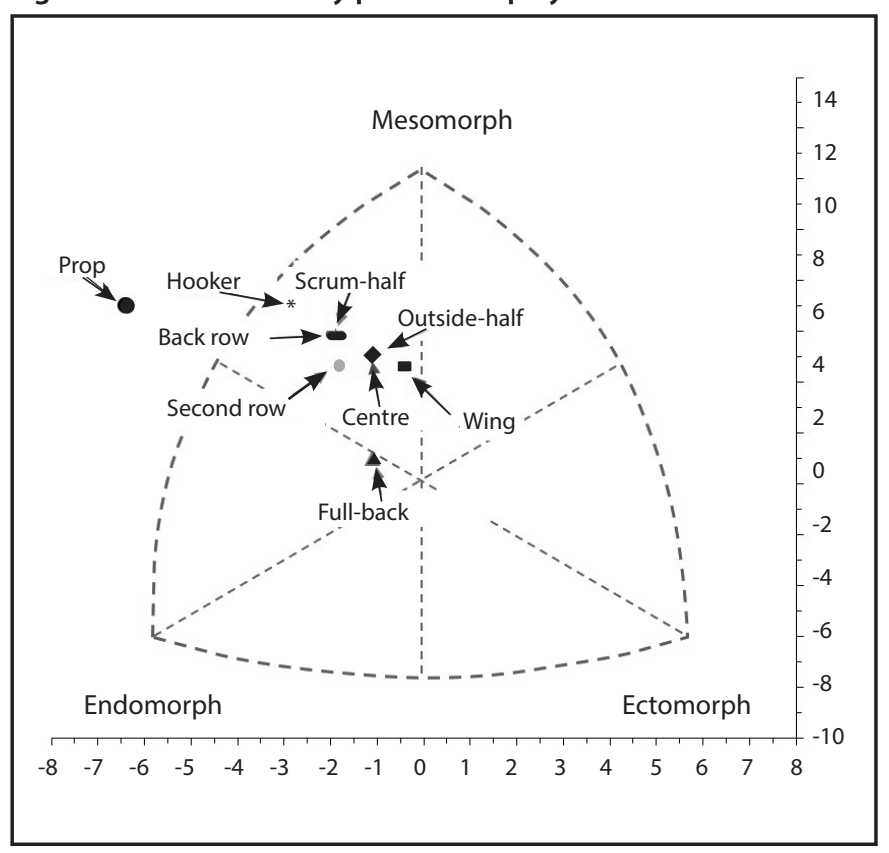

they are the first data obtained, they will reveal physical aspects of rugby players in this age group in Spain which could help improve talent identification, training methodologies, injury-prevention strategies and the monitoring of variations in body composition during the season ${ }^{1,15}$

This study shows that the U18 and U20 international rugby squads are of similar height, which is consistent with other research which observed no significant differences between the U18 and U20 categories in rugby ${ }^{20-22}$. However, body mass is greater in the $\mathrm{U} 20$ squad, a result which coincides with studies at rugby academies in the United Kingdom, where they observed greater body mass in under-20s compared 
to under- $18 \mathrm{~s}^{20-22}$. The body fat percentage and the sum of folds are also higher in the U20 squad, but this differs from other studies that have shown that the sum of folds is similar at these ages ${ }^{20-22}$. That the U18 and U20 players are of similar height can be explained by the fact that only minimal changes in height are expected after the age of 18 , and most of the players will have almost reached adult height by this point in their lives. By contrast, body mass would be expected to continue to rise with the intensification of the demands of competition and training (intensification of strength training programmes) ${ }^{4}$. The higher body fat percentage and sum of folds in the U20 squad is striking. This can be explained by the desire to increase body mass because this has been shown to increase linear momentum in tackling and physical collision ${ }^{4}$. A study focusing on rugby league also suggests that increasing the folds can protect players against the high number of collisions experienced in the sport ${ }^{23}$. Although an association between a low body fat percentage and enhanced performance has been demonstrated ${ }^{4,24,25}$, this can be explained by decreased acceleration on vertical and horizontal planes when the body fat percentage rises.

The difference in body mass, height, body fat percentage, sum of folds, skeletal muscle mass and somatotype between forwards and backs observed in this study is consistent with others, in both teenage $\mathrm{e}^{7,26-28}$ and adult ${ }^{4,29}$ rugby players. The data on the mean body mass of $U 18$ players given in the few studies published to date are not uniform. The mean results from this study are similar to those observed in U18 players in South Africa ${ }^{30}$, which gave $94.2 \pm 8.5 \mathrm{~kg}$ for forwards and $77.8 \pm 8.8 \mathrm{~kg}$ for backs $(p=0.66)$, but greater than the study conducted with players of a similar age in Ireland $(p<0.05)$, in which the forwards weighed $83.6 \pm 10.5$ $\mathrm{kg}$ and the backs $73.6 \pm 6.6 \mathrm{~kg}^{7}$.

The height of the U18 forwards observed in this study is similar ( $p=0.48$ ) to the heights seen in other studies focusing on players of a similar age, with forwards measuring $1.82 \pm 0.07 \mathrm{~m}$ and backs $1.78 \pm 0.05$ $\mathrm{m}^{7}$. The comparison of the body fat percentage in the U18 forwards and backs is smaller $(p<0.05)$ than what can be observed in other studies of players of the same age, which show $18 \%$ and $14 \%$, respectively ${ }^{7,30}$. Somatotyping the forwards and backs in the U18 squad, differences (SDD>2) can be observed when compared with the results of a study conducted with players in New Zealand ${ }^{28}$. In the forwards, mesomorphism is predominant over endomorphism, and both are predominant over ectomorphism, with slightly lower mesomorphism values than the aforementioned study of players of a similar age, which cited 5.6, and slightly higher endomorphism values than the same study, which found 3.428. Meanwhile, in the backs, mesomorphism is predominant over both endomorphism and ectomorphism, but the values are lower in mesomorphism and ectomorphism compared to the aforementioned study of players of a similar age, which indicated 5.5 and 2.3, while endomorphism gave a slightly higher figure than the New Zealand study, which cites 2.228. In the U20 forwards and backs, a greater body mass is observed ( $p<0.05)$ compared with studies of players of a similar age ${ }^{26,27}$ but a lower body mass when compared with top-flight adult players, which stands at $108 \pm 8 \mathrm{~kg}$ in forwards and $94 \pm 8 \mathrm{~kg}$ in backs 4 . The U20 forwards and backs in this study are taller $(p<0.05)$ than those of a similar age in other studies, in which the forwards measured $1.80 \pm 0.04$ and the backs $1.77 \pm 0.03 \mathrm{~m}^{26}$, but of a similar height to the adult players measured in a study in Spain, in which the forwards stood at $1.82 \pm 0.07 \mathrm{~m}$ and the backs at $1.79 \pm 0.09$ $\mathrm{m}^{31}$. Meanwhile, the body fat percentage found in the $\mathrm{U} 20$ forwards and backs is similar to that of adult international players ${ }^{4}$ but lower than that found in adult players in Spain ${ }^{31}$. Somatotyping the forwards and backs in the U20 squad, differences (SDD>2) can be observed when compared with the results of a previous study conducted with players of the same age $^{28}$. Mesomorphism is predominant in the forwards, the results being similar to another study with players of the same age, which gave 5.9, but the present study shows greater endomorphism than that same study, which indicated 3.628. Although mesomorphism predominates in the somatotype values of the U20 backs, it is lower than the value of 5.4 observed in players of a similar age, while endomorphism is higher than the study in New Zealand, which stood at 2.428. The differences observed between forwards and backs can be explained by the roles of each group in the game. The forwards are frequently involved in physical confrontation, which includes actions such as tackling, competing in scrums and rucking, and body mass and height are factors positively correlated with success during play ${ }^{32}$. The backs need to gain ground carrying the ball and score points by running through open space, and are typically involved in actions such as repeated high-speed sprints and shows of skill ${ }^{33}$.

In this study, the players are categorised into 9 positions. Comparisons show that the body mass of props is greater than that of other positions, with a mean which is higher $(p<0.05)$ than a study of Argentinean adults, which showed a body mass of $105 \pm 10 \mathrm{~kg}^{34}$, but similar $(p=0.22)$ to that of Italian adult internationals, which stood at $116 \pm 6 \mathrm{~kg}^{29}$. The greater body mass of props is understandable because they are the driving force in scrums and are constantly involved in rucks, mauls and tackles. The second-row forwards are taller, being similar in height ( $p=0.5)$ to the adult players who competed in a national tournament in Argentina, who measured $1.89 \pm 0.04 \mathrm{~m}^{34}$, and slightly shorter $(p<0.05)$ than the subjects in a study of adult international players, who were $1.97 \pm 0.02 \mathrm{~m}^{29}$. The second-row forwards are usually the tallest players because they are the ones who jump the most at lineouts and try to gain possession of the ball at kick-off. The props show the highest body fat percentage, similar ( $p=0.35$ ) to the $20 \pm 3 \%$ observed in adult internationals ${ }^{29}$. This higher body fat percentage can be explained by the demands of the position, and the objective is to absorb impact in collisions and tackles. In terms of somatotype, the props show greater endomorphism, although the somatotype is different from that observed in adult players (SDD $>2$ ), with greater endomorphism $(p<0.05)$ than that observed in other studies with adults: $4.9 \pm 1.134$. The props also show greater mesomorphism, although the values are lower $(p<0.05)$ than those obtained in a study with adult players, which indi- 
cated $8.1 \pm 0.234$. These results reflect the specific requirements of the position: high bone and muscle mass for scrums ${ }^{35}$.

Study and analysis in recent years has shown that the anthropometric profile is a key determinant for success in high-level rugby36. Therefore, the information obtained in this study needs to be added to the tactical, physical and psychological characteristics related to the specific demands of the game.

\section{Conclusions}

The elite rugby players in the Spain U20 squad have a greater body mass, body fat percentage and skeletal muscle mass than their U18 counterparts.

The elite rugby players in the Spain U18 and U20 squads are of similar height.

The elite forwards in the Spain U18 and U20 rugby squads have a greater body mass, height, body fat percentage, skeletal muscle mass and bone mineral mass than the players in the backs group.

The props are the position with the greatest body mass and body fat percentage in the Spain U18 and U20 elite rugby categories.

The second-row forwards are the position with the tallest players in the Spain U18 and U20 elite rugby categories.

The data obtained will help us create normative values for talent identification, training guidelines, dietary interventions and the control of performance improvements.

\section{Study limitations}

Other factors can also influence body composition besides training and competitive games, such as diet and activity outside competitive games and training. Although the players followed similar dietary and training guidelines, it would be impossible to control these variables, and we do not know what influence they may have on body composition and the differences between categories.

\section{Acknowledgments}

The Spanish Rugby Federation collaborated with this study.

\section{Conflict of Interests}

The authors declare that they are not subject to any type of conflict of interest.

\section{Bibliography}

1. Duthie G, Pyne D, Hooper S. Applied physiology and game analysis of rugby union. Sports Med. 2003;33:973-91.

2. Lindsay A, Draper N, Lewis J, Gieseg SP, Gill N. Positional demands of professional rugby. Eur J Sports Exerc Sci. 2015;15:480-7.

3. Crewther BT, Potts N, Kilduff LP, Drawer S, Cook CJ. Performance indicators during international rugby union matches are influenced by a combination of physiological and contextual variables. J Sci Med Sport. 2020;23:396-402.
4. Brazier J, Antrobus M, Stebbings GK, Day SH, Callus P, Erskine RM, et al. Anthropometric and Physiological Characteristics of Elite Male Rugby Athletes.J Strength Cond Res. 2018.

5. Jones MR, West DJ, Crewther BT, Cook CJ, Kilduff LP. Quantifying positional and tempora movement patterns in professional rugby union using global positioning system. Eur J Sports Exerc Sci. 2015;15:488-96.

6. Cahill N, Lamb K, Worsfold P, Headey R, Murray S. The movement characteristics of English Premiership rugby union players. J Sports Sci. 2013;31:229-37.

7. Delahunt E, Byrne RB, Doolin RK, McInerney RG, Ruddock CT, Green BS. Anthropometric profile and body composition of Irish adolescent rugby union players aged 16-18. J Strength Cond Res. 2013;27:3252-8.

8. Austin D, Gabbett T, Jenkins D. The physical demands of Super 14 rugby union. J SCi Med Sport. 2011;14:259-63.

9. Olds T. The evolution of physique in male rugby union players in the twentieth century J Sports Sci. 2001;19:253-62.

10. Keim NL, Belko AZ, Barbieri TF. Body fat percentage and gender: associations with exercise energy expenditure, substrate utilization, and mechanical work efficiency. Int J Sport Nutr. 1996;6:356-69.

11. Alsop JC, Morrison L, Williams SM, Chalmers DJ, Simpson JC. Playing conditions, player preparation and rugby injury: a case-control study. J Sci Med Sport. 2005:8:171-80.

12. Gabbett TJ. Physiological characteristics of junior and senior rugby league players. $\mathrm{Br}$ J Sports Med. 2002;36:334-9.

13. Carlson BR, Carter JE, Patterson P, Petti K, Orfanos SM, Noffal GJ. Physique and motor performance characteristics of US national rugby players. J Sports Sci. 1994;12:403-12.

14. Nicholas CW. Anthropometric and physiological characteristics of rugby union football players. Sports Med. 1997;23:375-96.

15. Duthie GM, Pyne DB, Hopkins WG, Livingstone S, Hooper SL. Anthropometry profiles of elite rugby players: quantifying changes in lean mass. Br J Sports Med. 2006:40:202-7.

16. Carter JEL. Body Composition of Montreal Olympic athletes. En: Carter J (ed). Physical structure of Olympic athletes. Part I The Montreal Olympic Games Anthropological Project. Basel, Switzerland: Karger; 1982;107-16.

17. Lee RC, Wang Z, Heo M, Ross R, Janssen I, Heymsfield SB. Total-body skeletal muscle mass: development and cross-validation of anthropometric prediction models. Am J Clin Nutr. 2000;72:796-803.

18. Rocha M. Peso osseo do brasileiro de ambos os sexo de 17 a 25 anos. Rio de Janeiro

19. Carter JEL. The Heath-Carter Anthropometric Somatotype. Instruction Manual. 2002. fuente: http://www.somatotype.org/Heath-CarterManual.pdf

20. Darrall-Jones JD, Jones B, Till K. Anthropometric and physical profiles of English academy rugby union players. J Strength Cond Res. 2015;29:2086-96.

21. Darrall-Jones JD, Jones B, Till K. Anthropometric, sprint, and high-intensity running profiles of English academy rugby union players by position. J Strength Cond Res. 2016;30:1348-58.

22. Till K, Tester E, Jones B, Emmonds S, Fahey J, Cooke C. Anthropometric and physical characteristics of English academy rugby league players. J Strength Cond Res. 2014;28:319-27.

23. Meir RA. Seasonal changes in estimates of body composition in professional rugby league players. Sport Health. 1993;11:27-31.

24. Fontana FY, Colosio AL, Da Lozzo G, Pogliaghi S. Player's success prediction in rugby union: From youth performance to senior level placing. J Sci Med Sport. 2017;20:409-14.

25. Pasin F, Caroli B, Spigoni V, Dei Cas A, Volpi R, Galli C, et al. Performance and anthropometric characteristics of Elite Rugby Players. Acta Biomed. 2017;88:172-7.

26. Vaz L, Vasilica I, Carreras D, Kraak W, Nakamura FY. Physical fitness profiles of elite under-19 rugby union players. J Sports Med Phys Fitness. 2016;56:415-21.

27. La Monica MB, Fukuda DH, Miramonti AA, Beyer KS, Hoffman MW, Boone CH, et al Physical differences between forwards and backs in American collegiate rugby players. J Strength Cond Res. 2016;30:2382-91.

28. Quarrie K, Handcock P, Waller AE, Chalmers D, Toomey M, Wilson B. The New Zealand rugby injury and performance project. III. Anthropometric and physical performance characteristics of players. Br J Sports Med. 1995;29:263-70.

29. Fontana FY, Colosio A, De Roia GF, Da Lozzo G, Pogliaghi S. Anthropometrics of Italian senior male rugby union players: from elite to second division. Int I Sports Physiol Perform. 2015;10:674-80.

30. Durandt J, Du Toit S, Borresen J, Hew-Butler T, Masimla H, Jokoet I, et al. Fitness and body composition profiling of elite junior South African rugby players. S Afr J Sports Med. 2006;18:38-45.

31. Suarez-Moreno A, Núñez F. Características fisiológico-antropométricas del jugador de rugby elite en España y la potencia relativa como predictor del rendimiento en sprint y RSA. J Sport Health Res. 2011;3:191-202. 
32. Quarrie KL, Hopkins WG, Anthony MJ, Gill ND. Positional demands of international rugby union: evaluation of player actions and movements. J Sci Med Sport. 2013;16:353-9.

33. GabbettTJ. A comparison of physiological and anthropometric characteristics among playing positions in sub-elite rugby league players. J Sports Sci. 2006;24:1273-80.

34. Holway FE, Garavaglia R. Kinanthropometry of group I rugby players in Buenos Aires, Argentina. J Sports Sci. 2009;27:1211-20.
35. Deutsch M, Kearney G, Rehrer N. Time-motion analysis of professional rugby union players during match-play. J Sports Sci. 2007;25:461-72

36. Sedeaud A, Marc A, Schipman J, Tafflet M, Hager J-P, Toussaint J-F. How they won Rugby World Cup through height, mass and collective experience. Br J Sports Med. 2012;46:580-4 